\title{
Transcriptome Profiling and Molecular Therapeutic Advances in Cystic Fibrosis: Recent Insights
}

\author{
Justin E. Ideozu ${ }^{1,2,3}$, Xi Zhang ${ }^{1,2,3}$, Susanna McColley ${ }^{1,3}$ and Hara Levy ${ }^{1,2,3, *}$ \\ 1 Ann \& Robert H. Lurie Children's Hospital of Chicago, Chicago, IL 60611, USA; \\ justin.ideozu@northwestern.edu (J.E.I.); XiZhang@luriechildrens.org (X.Z.); \\ SMcColley@luriechildrens.org (S.M.) \\ 2 Human Molecular Genetics Program, Stanley Manne Children's Research Institute, Chicago, IL 60614, USA \\ 3 Feinberg School of Medicine at Northwestern University Chicago, Chicago, IL 60611, USA \\ * Correspondence: HLevy@luriechildrens.org; Tel.: +1-773-755-6354
}

Received: 4 February 2019; Accepted: 21 February 2019; Published: 26 February 2019

\begin{abstract}
In cystic fibrosis (CF), mutations in the cystic fibrosis transmembrane conductance regulator (CFTR) gene disrupt the capacity of the encoded protein to function as a channel to transport chloride ions and water across cell membranes. The consequences are deleterious, system-wide, and immensely variable, even among patients with the same CFTR genotype. This underscores the need to characterize the mechanisms contributing to CF pathophysiology. Gene replacement and gene editing therapies have been pursued intensively and are expected to provide a one-time treatment for CF. However, gene replacement therapy is limited by the lack of efficient vectors to deliver functional copies of CFTR to cells without immunological complications, while gene editing technologies such as CRISPR/Cas9 are still in their infancy, mainly useful in somatic cells and limited by off-target insertions. Small molecule treatments targeted at potentiating or correcting CFTR have shown clinical benefits, but they are limited to a few CFTR mutations and insufficient to overcome challenges related to clinical heterogeneity. Transcriptome profiling approaches have emerged as robust tools capable of characterizing phenotypic variability and revealing novel molecular targets with therapeutic potential for CF. We summarize current insights gained through transcriptome profiling approaches in CF studies and recent advances in molecular therapeutics.
\end{abstract}

Keywords: cystic fibrosis; transcriptome profiling; molecular therapy; RNA-Seq; microarray

\section{Introduction: Cystic Fibrosis}

Cystic fibrosis (CF) is an autosomal recessive genetic disease due to mutations in the cystic fibrosis conductance regulator (CFTR) gene [1,2]. The gene encodes a member of the ATP-binding cassette $(\mathrm{ABC})$ transporter superfamily that functions as a channel to transport chloride ions and water across cell membranes. Disruption of this crucial CFTR function results in deleterious system-wide consequences that vary immensely among $\mathrm{CF}$ patients [3]. This underscores the need to characterize molecular mechanisms driving CF pathophysiology.

Although chronic progressive lung disease accounts for the vast majority of morbidity and mortality in $\mathrm{CF}$, it is a multisystem disease affecting several body organs [4]. With our in silico analysis of global gene expression datasets from the Genotype-Tissue Expression (GTEx) project based on 53 non-diseased tissue sites from $\sim 1000$ individuals confirming CFTR is abundantly expressed in several tissues (Figure 1), it is conceivable that CFTR mutations may result in multisystem consequences. 


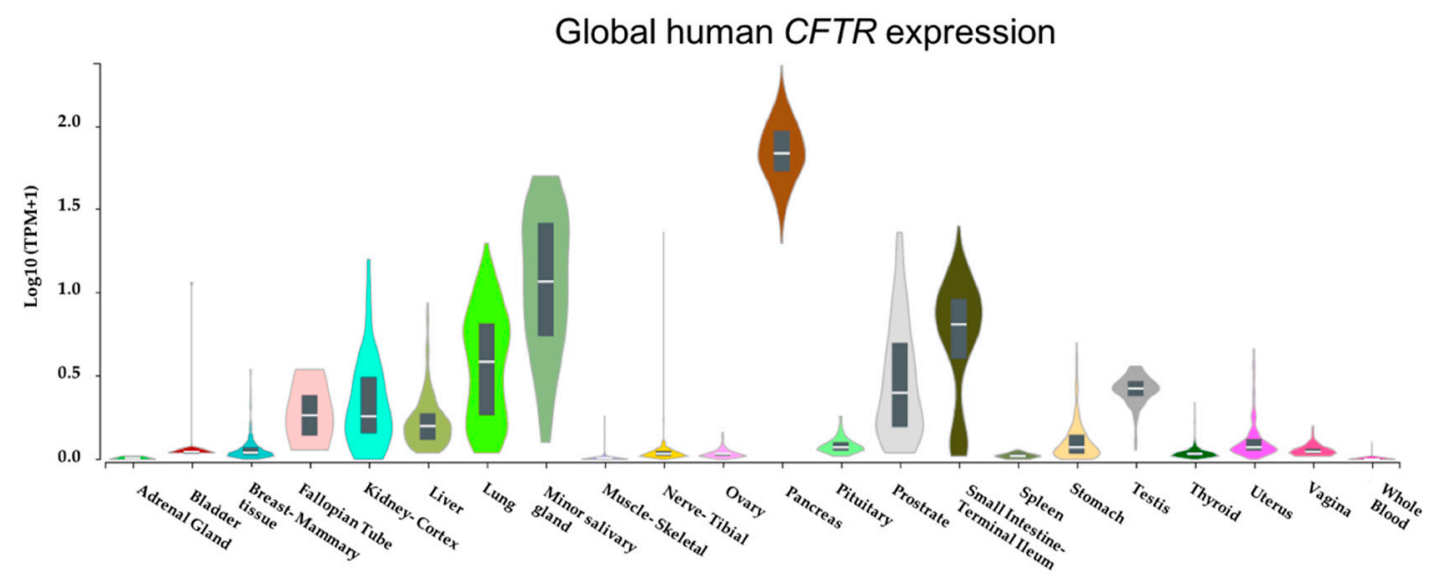

Figure 1. Cystic fibrosis transmembrane conductance regulator (CFTR) is abundantly expressed in many tissues. CFTR mRNA expression levels across several tissues were retrieved from Genotype-Tissue Expression (GTEx) Portal [5]. Expression values are shown in transcript per million (Log10) on the $y$-axis while $x$-axis represents tissues.

To date, over 2000 CFTR mutations have been identified (http:/ /www.genet.sickkids.on.ca/), with varying implications for the disease severity based on their interference with the structure and function of CFTR protein [4]. Gene replacement and gene editing therapies have been pursued intensively in search of a one-time cure for $\mathrm{CF}$, but these have so far not led to convincing clinical results $[6,7]$. In contrast, small molecules targeted at correcting or potentiating CFTR have shown clinical benefits in recent times but there are concerns these therapies do not cover all known CFTR mutations [7], suggesting they are insufficient to resolve challenges met with clinical heterogeneity. With evidence from CF twin sibling studies [8] and genome-wide association studies (GWAS) [9] demonstrating that modifier genes contribute to phenotypic outcomes and variability in $\mathrm{CF}$, there is a pressing need to better understand the underlying pathophysiological mechanisms of $\mathrm{CF}$ in order to identify novel molecular candidates that offer promise as predictors of prognosis or therapeutic targets.

Transcriptome profiling approaches have emerged as useful tools for delineating the transcriptome complexities in CF cells [10], in view of characterizing molecular mechanisms that contribute to the disease pathophysiology or identifying molecular targets with therapeutic potential. In this review, we provide current insights into the utilization of transcriptome profiling approaches in $\mathrm{CF}$ studies; we discuss prominent findings and advances of CF molecular therapies emphasizing on target identification via transcriptomics. We also discuss emerging areas for transcriptome profiling in $\mathrm{CF}$ and highlight some limitations of transcriptome profiling in CF.

\section{Transcriptome Profiling in Cystic Fibrosis}

In attempts to better understand the complex sequence of transcriptional events influenced by dysfunctional CFTR, many CF studies have utilized high-throughput transcriptome profiling approaches (Table 1). 
Table 1. Summary of human transcriptome profiling studies in cystic fibrosis.

\begin{tabular}{|c|c|c|c|c|c|}
\hline Year & Focus & Methods & Tissue/Cell & Key Enriched Pathways & Reference \\
\hline 2005 & $\begin{array}{c}\text { Transcriptional changes induced by CF } \\
\text { Pseudomonas aeruginosa and Burkholderia } \\
\text { cepacia }\end{array}$ & Microarray & $\begin{array}{c}\text { Alveolar } \\
\text { macrophages }\end{array}$ & $\begin{array}{l}\text { Cytokine signaling; NF- } \mathrm{KB} \\
\text { signaling }\end{array}$ & [11] \\
\hline 2006 & Mild vs. severe CF lung disease & Microarray & Epithelial & Ubiquitin cycle; lipid metabolism & [12] \\
\hline 2007 & CF vs. healthy controls & Microarray & Epithelial & $\begin{array}{l}\text { Activator protein } 1 \text { and NF- } \mathrm{kB} \\
\text { activator pathway }\end{array}$ & [13] \\
\hline 2009 & $\begin{array}{l}\text { Transcriptional changes induced by } \\
\text { Azithromycin }\end{array}$ & Microarray & Epithelial & $\begin{array}{l}\text { Lipid/cholesterol biosynthesis; } \\
\text { cell division }\end{array}$ & [14] \\
\hline 2011 & CF vs. non-CF samples & Microarray & Epithelial & $\begin{array}{l}\text { Inflammatory response; } \\
\text { cell-to-cell signaling; cellular } \\
\text { movement }\end{array}$ & [15] \\
\hline 2012 & $\begin{array}{l}\text { Transcriptional changes induced by CF } P . \\
\text { aeruginosa }\end{array}$ & Microarray & Epithelial & $\begin{array}{l}\text { TLR signaling; chemokine } \\
\text { signaling }\end{array}$ & [16] \\
\hline 2012 & $\begin{array}{l}\text { Transcriptional changes induced by plasma } \\
\text { of CF and non-CF }\end{array}$ & Microarray & PBMCs & $\begin{array}{l}\text { Immune response, B- and T-cell } \\
\text { activation }\end{array}$ & [17] \\
\hline 2013 & CF vs. healthy controls & Microarray & Epithelial & Inflammation; defense response & [18] \\
\hline 2013 & $\begin{array}{l}\text { Transcriptional changes induced by innate } \\
\text { defense regulator } 1018\end{array}$ & Microarray & $\begin{array}{l}\text { Epithelial, } \\
\text { PBMCs }\end{array}$ & $\begin{array}{l}\text { Dysfunctional autophagy, } \\
\text { AMPK-Akt signaling }\end{array}$ & [19] \\
\hline 2013 & $\begin{array}{l}\text { Transcriptional changes influenced by a CF } \\
\text { modifier gene- } E H F\end{array}$ & Microarray & Epithelial & $\begin{array}{l}\text { Gene regulation; glycosylation of } \\
\text { biopolymers }\end{array}$ & [20] \\
\hline 2014 & $\begin{array}{l}\text { Transcriptional changes influenced by CF } \\
\text { and other lung diseases }\end{array}$ & Microarray & Blood, PBMCs & $\begin{array}{l}\text { Immune response, leukocyte } \\
\text { activation in immune response }\end{array}$ & [21] \\
\hline 2014 & $\begin{array}{l}\text { Transcriptional changes induced by } \\
\text { oxidative stress }\end{array}$ & Microarray & Epithelia & $\begin{array}{l}\text { Cell survival; regulation of signal } \\
\text { transduction }\end{array}$ & [22] \\
\hline 2015 & Transcriptional changes influenced by CF & Microarray & Lymphoblasts & $\begin{array}{l}\text { Endomembrane function; ER } \\
\text { response to stress }\end{array}$ & [23] \\
\hline 2017 & Mild vs. severe lung phenotype & RNA-Seq & Leukocytes & $\begin{array}{l}\text { Type } 1 \text { interferon response; } \\
\text { protein targeting ER }\end{array}$ & [10] \\
\hline 2017 & $\begin{array}{l}\text { Transcriptional changes induced by } \\
\text { digitoxin }\end{array}$ & Microarray & Epithelial & $\begin{array}{l}\text { Inflammatory pathway; immune } \\
\text { response }\end{array}$ & [24] \\
\hline 2018 & $\begin{array}{l}\text { Transcriptional changes influenced by } \\
\text { genomic variation }\end{array}$ & RNA-Seq & Epithelial & $\begin{array}{l}\text { Inflammation/inflammatory } \\
\text { signaling; innate immune } \\
\text { response }\end{array}$ & [25] \\
\hline 2018 & $\begin{array}{l}\text { CF before vs. after treatment for } \\
\text { exacerbation }\end{array}$ & RNA-Seq & $\begin{array}{l}\text { Blood, } \\
\text { neutrophils }\end{array}$ & $\begin{array}{l}\text { Functional enrichment not } \\
\text { performed; inflammasome genes }\end{array}$ & [26] \\
\hline 2018 & $\begin{array}{l}\text { Transcriptional changes induced by plasma } \\
\text { of CF and its phenotypes }\end{array}$ & Microarray & PBMCs & $\begin{array}{l}\text { E1F2 Signaling, IL-8 signaling, } \\
\text { B-cell receptor, production of } \\
\text { nitric oxide and oxygen reactive } \\
\text { species }\end{array}$ & [27] \\
\hline
\end{tabular}

CF, cystic fibrosis; NF-кB, nuclear factor kappa B; TLR, Toll-like receptor; AMPK, AMP-activated protein kinase; ER, endoplasmic reticulum; IL, interleukin; PBMC, peripheral blood mononuclear cell.

Transcriptome profiling provides a robust approach for simultaneous quantification of the expression signatures of all transcripts within a cell and to assess their expression differences across various physiological conditions [28]. When used in combination with in silico functional genomics approaches, complex mechanisms underlying the pathophysiology of many diseases can be deciphered [29-31]. Microarray and RNA-Sequencing are two powerful transcriptome profiling technologies that have proven resourceful for deducing and quantifying transcriptomes in many CF studies. While microarray array solutions are hybridization-based and focus on quantifying a predefined set of transcripts, RNA-Sequencing is sequence-based and offers an unbiased quantification of all transcripts within a cell without prior knowledge of a particular gene. In addition, RNA-Sequencing can provide information regarding alternative splicing and sequence variation in the captured genes [28,32]. A detailed review of transcriptome profiling approaches and advances in other human diseases are described elsewhere [28]. In CF, transcriptome profiling approaches are opening new horizons that will enhance our understanding of the disease pathology and unravel novel therapeutic targets (Table 1).

As shown in Table 1, microarray has been the most used transcriptome profiling approach in CF studies and most have investigated epithelial cells, which are the dominant cell-type affected by CFTR dysfunction in CF lung [33]. These studies have addressed questions ranging from identifying distinct genes that distinguish $\mathrm{CF}$ and its phenotypes to evaluating transcriptional responses of CF cells to external stimuli. 
Alveolar macrophages (AM) were one of the earliest immune cells subjected to transcript profiling in CF. AM reside on the epithelial surface of the lung and play a crucial role in pathogen clearance [34], a process that is compromised in the CF lung $[35,36]$. Following stimulation of AM with early and late strains of CF Pseudomonas aeruginosa and Burkholderia cepacia, significant expression changes in genes involved in inflammatory pathways and signaling systems were observed, though similar responses were observed between early and late strains of both bacteria species [11]. This suggests that other host immune factors may be involved with the variable pulmonary phenotypes seen among CF patients.

As systemic markers have the potential to reflect the inflammation profile of the CF lung, blood cells have also emerged as targets for transcriptome profiling to delineate host immune factors associated with CF pathophysiology $[17,19,26]$. Transcriptional profiling has been direct, by assessing gene expression differences in CF blood cells [21,26] or indirect, by assessing transcriptional responses of blood cells exposed to CF-associated external stimuli [17,27], as previously described [37]. Although few studies have evaluated blood cells via transcriptomics in CF (Table 1), we have shown using microarray profiling that transcriptional signatures of peripheral blood mononuclear cells (PBMCs) exposed to plasma from patients with $\mathrm{CF}$ or from healthy controls $(\mathrm{HC})$ can distinguish $\mathrm{CF}$ disease state from non-CF and characterizes its phenotypes. Like others (Table 1), we identified several genes that encode molecules within important biological pathways, especially those of the immune system are dysregulated in CF $[17,27]$. Others have also shown that transcriptional responses of PBMCs can enhance our understanding of immune dysfunction in CF. Following microarray profiling of CF PBMCs stimulated with flagellin, elevated levels of critical autophagosome marker LC3-II were observed. The elevated levels were effectively abolished by innate defense regulator (IDR)-1018, an anti-inflammatory peptide, which implicated dysfunctional autophagy for the exaggerated inflammatory responses seen in CF [19].

Further, a recent study utilizing transcriptome profiling by RNA-Sequencing of blood neutrophils identified 83 gene isoforms that demonstrated significant (False discovery rate-adjusted $p<0.05$ ) changes in expression levels following treatment for exacerbations in CF [26]. Although functional enrichment was not performed, the results are indicative that alternative splicing events may be relevant to CF disease progression. Collectively, as shown in Table 1, findings from CF transcriptome profiling studies indicate that genes involved in many important biological pathways are dysregulated in $\mathrm{CF}$.

\section{Cystic Fibrosis-Associated Genes and Their Pathways}

Pathway dysfunction is profound in $\mathrm{CF}$ and those involved in signal transduction and immune system are among the most documented in CF. Transcriptome profiling has identified key CF-associated genes relevant to the defective pathways (Table 2). We describe the prominent pathways here:

Table 2. Altered pathways in CF and associated genes.

\begin{tabular}{|c|c|c|c|}
\hline Gene & Gene Name & Relevant Pathway(s) & References \\
\hline \multicolumn{4}{|c|}{ Signal Transduction/Transport of Small Molecules } \\
\hline $\mathrm{CDH} 4$ & Cadherin 4 & Wnt signaling & [13] \\
\hline $\mathrm{CDH} 8$ & Cadherin 8 & Wnt signaling & [13] \\
\hline CDK6 & Cyclin dependent kinase 6 & PI3K/Akt signaling & {$[13,27]$} \\
\hline CHRM3 & Cholinergic receptor muscarinic 3 & Signaling by GPCR, Calcium signaling pathway & {$[22,27]$} \\
\hline ESR1 & Estrogen receptor 1 & Signaling by GPCR & {$[22,27]$} \\
\hline FGF2 & Fibroblast growth factor 2 & mTOR signaling, PI3K/Akt signaling & {$[13,27]$} \\
\hline ITGA4 & Integrin subunit $\alpha 4$ & PI3K/Akt signaling & [13] \\
\hline ITGA6 & Integrin subunit $\alpha 6$ & Signaling by GPCR, Wnt signaling & {$[13,27]$} \\
\hline JAG1 & Jagged 1 & PI3K/Akt signaling, Signaling by GPCR & {$[13,27]$} \\
\hline MMP9 & Matrix metallopeptidase 9 & Signaling by GPCR, Interleukin 4 \& 13 signaling & [22] \\
\hline NCF2 & Neutrophil cytosolic factor 2 & Signaling by GPCR & {$[22,27]$} \\
\hline $\mathrm{NOTCH} 3$ & Notch 3 & PI3K/Akt signaling, Signaling by GPCR & {$[13,27]$} \\
\hline NRP2 & Neuropilin 2 & Signaling by GPCR & {$[13,22,27]$} \\
\hline PIK3R1 & Phosphoinositide-3-kinase regulatory subunit 1 & mTOR signaling, PI3K/Akt signaling & {$[22,27]$} \\
\hline PSMA5 & Proteasome subunit $\alpha 5$ & Signaling by GPCR, Wnt signaling & {$[22,27]$} \\
\hline SFN & Stratifin & mTOR signaling, Signaling by GPCR & {$[13,27]$} \\
\hline SFRP1 & Secreted frizzled related protein 1 & Signaling by GPCR, Wnt signaling & {$[22,27]$} \\
\hline SOX9 & SRY-box 9 & Signaling by GPCR, Wnt signaling & {$[13,22,27]$} \\
\hline
\end{tabular}


Table 2. Cont.

\begin{tabular}{|c|c|c|c|}
\hline Gene & Gene Name & Relevant Pathway(s) & References \\
\hline STAT1 & Signal transducer and activator of transcription 1 & PI3K/Akt signaling, Signaling by GPCR & {$[22,27]$} \\
\hline WNT2B & Wnt family member 2B & Wnt/ $\beta$-catenin signaling, PI3K/Akt signaling & {$[13,27]$} \\
\hline \multicolumn{4}{|c|}{ Immune system } \\
\hline CTSB & Cathepsin B & Innate immune system, Bacterial infections in CF airways & [13] \\
\hline CXCL1 & C-X-C motif chemokine ligand 1 & Cytokines and inflammatory response, immune response & {$[13,22,27]$} \\
\hline CXCL10 & $\mathrm{C}-\mathrm{X}-\mathrm{C}$ motif chemokine ligand 10 & Cytokine signaling, Signaling by interleukins & {$[13,22,27]$} \\
\hline CXCL8 & C-X-C motif chemokine ligand 8 & $\begin{array}{l}\text { NFkB signaling, Innate immune system, Interleukin } \\
\text { signaling }\end{array}$ & {$[22,27]$} \\
\hline GHR & Growth hormone receptor & Cytokine signaling, innate immune system & [22] \\
\hline HMOX1 & Heme oxygenase 1 & $\begin{array}{c}\text { NFkB signaling, Cytokine signaling; Innate immune } \\
\text { system }\end{array}$ & {$[13,22]$} \\
\hline ICAM1 & Intercellular adhesion molecule 1 & Cytokine signaling, Signaling by interleukins & {$[13,27]$} \\
\hline$I L 1 A$ & Interleukin $1 \alpha$ & $\begin{array}{c}\text { NFkB, T-cell receptor signaling, IFN } \alpha \& \beta \text { immune } \\
\text { response }\end{array}$ & {$[13,22,27]$} \\
\hline$I L 1 B$ & Interleukin $1 \beta$ & Cytokine signaling, immune response, Lung fibrosis & {$[13,22,27]$} \\
\hline IL6 & Interleukin 6 & Cytokine signaling, immune response & {$[13,22,27]$} \\
\hline ITGA4 & Integrin subunit $\alpha 4$ & $\begin{array}{c}\text { Transcriptional regulation by RUNX3, Generic } \\
\text { transcription }\end{array}$ & {$[13]$} \\
\hline LY96 & Lymphocyte antigen 96 & NFkB signaling, Innate immune system & {$[13,27]$} \\
\hline$M M E$ & Membrane metalloendopeptidase & B-cell development pathways, innate immune system & [13] \\
\hline$M M P 1$ & Matrix metallopeptidase 1 & Cytokine signaling, immune response & [13] \\
\hline NOX4 & NADPH oxidase 4 & Immune cell transmigration, PAK pathway & [13] \\
\hline PTGS2 & Prostaglandin-endoperoxide synthase 2 & $\begin{array}{c}\text { NFkB signaling, Cytokine signaling; Innate immune } \\
\text { system }\end{array}$ & [13] \\
\hline RASGRP1 & RAS guanyl releasing protein 1 & T-cell receptor signaling; Cytokine signaling & {$[13,22,27]$} \\
\hline SERPINA1 & Serpin family A member 1 & Innate immune system, Lung fibrosis & {$[13,22,27]$} \\
\hline TLR4 & Toll like receptor 4 & NFkB signaling, Innate immune system, TREM1 signaling & {$[13,27]$} \\
\hline VEGFA & Vascular endothelial growth factor A & Innate immune system, Signaling by interleukins & [13] \\
\hline
\end{tabular}

CF, cystic fibrosis; GPCR, G-protein coupled receptor; IL, interleukin; PI3K, phosphoinositide 3-kinase; NF- $\mathrm{kB}$, nuclear factor kappa B; TREM, Triggering Receptor Expressed on Myeloid Cells; RUNX3, Runt Related Transcription Factor 3; PAK, p21-activated protein kinase; IFN, interferon.

\subsection{Signal Transduction Pathways}

Signal transduction is essential for diverse cellular and molecular events including cell growth, proliferation, metabolism, and gene expression [38]. Several signaling pathways are defective in CF. For example, the PI3K/Akt/mTOR signaling pathway [39] is important for cell cycle regulation, with mTOR activation crucial in regulating cell autophagy [40]. Following mass spectrometry and functional analysis, it was found that mTORC1/2 and Eukaryotic Initiation Factor (EIF) signaling complexes interact with CFTR, mTOR is activated in CF bronchial epithelial cells, and the $\mathrm{PI} 3 \mathrm{~K} / \mathrm{Akt} / \mathrm{mTOR}$ pathway is inhibited in CF. Interestingly, the study also showed that inhibition of this pathway led to increased expression and stability of CFTR [39]. Thus, suggested the PI3K/Akt/mTOR pathway as a potential therapeutic target for CF. As another example, transcriptional profiling of CF PBMCs exposed to multiple bacterial ligands revealed that dysfunctional autophagy was implicated for heightened inflammatory responses and AMPK-Akt signaling was identified as a potential anti-inflammatory target [19]. We recently identified activated EIF2 signaling pathway as the most significant pathway associated with CF via microarray profiling using a plasma-induced PBMCs model [27]. Follow-up studies are needed to understand the mechanisms involved. Other signal transduction pathways associated with CF include Wnt/ $\beta$-Catenin Signaling [41], G-protein coupled receptors (GPCR), and $\mathrm{Ca}^{2+}$ signaling pathway [1].

\subsection{Immune System Pathways}

Aberrant immune responses are prominent in CF. Dysfunctional CFTR leading to defective NF- $\kappa B$ signaling and neutrophilic inflammation is one of the most documented features of CF lung disease [42]. $\mathrm{NF}-\mathrm{kB}$ mediates the expression of pro-inflammatory genes such as cytokines and chemokine, thereby playing a crucial role in regulating immune response [43]. CF fetal lungs were shown to have elevated NF- $\kappa B$ levels prior to pathogen exposure and increased activation of NF- $\kappa B$ regulated genes compared to the non-CF [44], implicating dysfunctional CFTR as the chief cause of the defective NF- $\mathrm{KB}$ signaling. Also, via gene expression profiling, several NF- $\mathrm{kB}$ proinflammatory genes were found to be over-expressed in CF cells in comparison to control cells. The activation of NF- $\mathrm{kB}$ was correlated with higher inhibitor of kappaB kinase (IKK) and activator protein-1 (AP-1) activity [13]. 
While these observations focused on epithelial cells, transcriptome profiling of AM induced with CF P. aeruginosa and with B. cepacian resulted in enriched NF-KB and cytokine signaling pathways [11]. Other dysregulated CF-associated immune pathways captured via transcriptome profiling of blood cells include altered immune response, B-and T-cell activation [17], cytokine signaling [11], and Type 1 interferon response [10] (Table 1).

\section{Molecular Advances in Developing Therapeutics for Cystic Fibrosis}

Over the past decade, commendable progress has been made in the search for novel molecular therapies for CF. Gene therapy by replacing or editing CF-associated molecules are at the forefront in this context. We summarize recent advances.

\subsection{Gene Replacement Therapy and Gene Editing}

Since the discovery of the CFTR gene in 1989, gene replacement therapy has been pursued extensively as an option to replace mutated CFTR in CF cells with functional copies of the gene. The approach is promising as a one-time treatment for people with $\mathrm{CF}$, but thus far, it has not led to convincing clinical results [6]. A major barrier to gene replacement therapy is the development of efficient vectors that enable safe delivery of functional CFTR to CF cells without immunological complications [7]. Addressing the barriers to gene transfer is expected to lead to the generation of effective molecular therapy for CF [7]. In contrast to gene replacement, gene editing approaches are aimed at using nucleases to enzymatically correct mutated genes in their native location in a cell. Several gene editing tools exist but one of the most revolutionary gene editing tools that hold promise for correcting mutated CFTR and restoring its function is CRISPR/Cas9 [45]. The technology uses a protein-RNA complex composed of Cas9 enzyme that binds to a guide RNA (gRNA) molecule to recognize the targeted DNA sequences. When utilized to repair CFTR locus in human intestinal stem cells, the technology robustly restored CFTR function [46]. Although the technology also faces barriers such as off-target insertion [47], it remains at the forefront in the search for a one-time cure for CF. Detailed review of recent advances in CF gene therapy are described elsewhere [7].

\subsection{Cystic Fibrosis-Associated Molecules: Small and Large Molecular Targets for Treating Cystic Fibrosis}

Although gene therapy has not yielded convincing clinical benefits, progress in therapeutics to relieve CF symptoms has been based on an increased understanding of the basic CFTR defects and the identification of novel molecular markers using advanced genetic technologies. Generally, mutations fall into six classes based on the mechanism by which they disrupt the structure and function of CFTR. The dysfunction may be due to the lack of CFTR protein synthesis (Class 1), failure of CFTR to reach cell surface due to misfolding and degradation (Class 2), reduced CFTR channel opening due to defects in gating (Class 3), reduced chloride conductance due channel defects (Class 4), reduced CFTR synthesis due to abnormal splicing (Class 5), and reduced CFTR stability at the cell surface (Class 6) [6].

Small molecule pharmacological agents developed to target basic CFTR defects have already yielded remarkable results in clinical trials (Table 3). These agents are termed CFTR modulators and include CFTR potentiators, correctors, and amplifiers. Potentiator therapies such as Ivacaftor increase flow of chloride ions by activating the CFTR channels. Thus, are helpful for CF patients with gating defects (Class 3) [48]. Correctors such as lumacaftor and tezacaftor facilitate proper maturation and delivery of CFTR protein to the cell surface. Patients with Class 2 CFTR mutation are the primary targets for correctors. 
Table 3. Gene targets and therapeutic advances.

\begin{tabular}{|c|c|c|c|c|c|c|}
\hline Drug Name & Phase & Type & Status & Activity & Target & Target Class \\
\hline Ivacaftor, lumacaftor & 4 & SM & Completed & Agonist & CFTR & $\begin{array}{l}\text { Cystic fibrosis transmembrane } \\
\text { conductance regulator (CFTR) }\end{array}$ \\
\hline Doxycycline & 4 & SM & Completed & Antagonist & $M M P 7$ & Metallo protease M10A subfamily \\
\hline Doxycycline & 4 & SM & Completed & Antagonist & $M M P 1$ & Metallo protease M10A subfamily \\
\hline Cholecalciferol & 4 & SM & Completed & Agonist & $V D R$ & $\begin{array}{c}\text { Nuclear hormone receptor subfamily } 1 \\
\text { group I member } 1\end{array}$ \\
\hline Doxycycline & 4 & SM & Completed & Antagonist & MMP13 & Metallo protease M10A subfamily \\
\hline Doxycycline & 4 & SM & Completed & Antagonist & MMP8 & Metallo protease M10A subfamily \\
\hline Somatropin & 3 & Protein & Completed & Agonist & GHR & Membrane receptor \\
\hline Denufosol & 3 & SM & Completed & Agonist & P2RY2 & Purine receptor \\
\hline Insulin glargine & 3 & Protein & Completed & Agonist & INSR & Tyrosine protein kinase InsR family \\
\hline Prednisone & 3 & SM & Recruiting & Agonist & $N R 3 C 1$ & $\begin{array}{c}\text { Nuclear hormone receptor subfamily } 3 \\
\text { group C member } 1\end{array}$ \\
\hline Tiotropium & 3 & SM & Completed & Antagonist & CHRM3 & Acetylcholine receptor \\
\hline Nitric oxide & 2 & SM & Recruiting & Agonist & GUCY1A2 & Soluble guanylate cyclase \\
\hline PTI-428 & 2 & SM & Completed & Agonist & CFTR & CFTR \\
\hline pGM169/GL67A & 2 & SM & Completed & Agonist & CFTR & CFTR \\
\hline Digitoxin & 2 & SM & Completed & Antagonist & АТР1B3 & Hydrolase \\
\hline Nitric oxide & 2 & SM & Completed & Agonist & GUCY1B1 & Soluble guanylate cyclase \\
\hline Nitric oxide & 2 & SM & Completed & Agonist & GUCY1B2 & Soluble guanylate cyclase \\
\hline Nitric oxide & 2 & SM & Completed & Agonist & GUCY1A1 & Soluble guanylate cyclase \\
\hline Gallium nitrate & 2 & SM & Completed & Antagonist & RRM2 & Enzyme \\
\hline Sildenafil & 2 & SM & Active & Antagonist & PDE5A & Phosphodiesterase 5A \\
\hline Digitoxin & 2 & SM & Completed & Antagonist & ATP1A1 & Hydrolase \\
\hline Omeprazole & 2 & SM & Recruiting & Antagonist & $A T P 4 B$ & Hydrogen potassium ATPase \\
\hline Miglustat & 2 & SM & Completed & Antagonist & UGCG & Transferase \\
\hline P-1037 & 2 & SM & Completed & Antagonist & SCNN1B & Epithelial sodium channel \\
\hline Gallium nitrate & 2 & SM & Completed & Antagonist & RRM2B & Enzyme \\
\hline Fiboflapon & 2 & SM & Completed & Antagonist & ALOX5AP & Other cytosolic protein \\
\hline Losartan & 2 & SM & Recruiting & Antagonist & AGTR1 & Angiotensin receptor \\
\hline Digitoxin & 2 & SM & Completed & Antagonist & FXYD2 & Hydrolase \\
\hline Digitoxin & 2 & SM & Completed & Antagonist & ATP1A2 & Hydrolase \\
\hline Digitoxin & 2 & SM & Completed & Antagonist & ATP1B2 & Hydrolase \\
\hline Amiloride & 2 & SM & Completed & Antagonist & SCNN1A & Epithelial sodium channel \\
\hline P-1037 & 2 & SM & Completed & Antagonist & SCNN1G & Epithelial sodium channel \\
\hline Digitoxin & 2 & SM & Completed & Antagonist & ATP1A4 & Hydrolase \\
\hline Digitoxin & 2 & SM & Completed & Antagonist & АTP1A3 & Hydrolase \\
\hline Digitoxin & 2 & SM & Completed & Antagonist & ATP1B1 & Hydrolase \\
\hline Gallium nitrate & 2 & SM & Completed & Antagonist & RRM1 & Enzyme \\
\hline Simvastatin & 1 & SM & Completed & Antagonist & HMGCR & Oxidoreductase \\
\hline Hydroxychloroquine & 1 & SM & Completed & Antagonist & TLR9 & Toll-like and Il-1 receptors \\
\hline Amelubant & 1 & SM & Completed & Antagonist & LTB4R & Leukotriene receptor \\
\hline Pioglitazone & 1 & SM & Completed & Agonist & PPARG & $\begin{array}{c}\text { Nuclear hormone receptor subfamily } 1 \\
\text { group C member } 3\end{array}$ \\
\hline Interferon $\gamma-1 \mathrm{~b}$ & 1 & Protein & Completed & Agonist & IFNGR2 & Membrane receptor \\
\hline Hydroxychloroquine & 1 & SM & Completed & Antagonist & TLR7 & Toll-like and Il- 1 receptors \\
\hline Interferon $\gamma-1 b$ & 1 & Protein & Completed & Agonist & IFNGR1 & Membrane receptor \\
\hline
\end{tabular}

SM: Small molecule; InsR, insulin receptor; IL, interleukin. Source: Open target platform [49].

As both transport of chloride ions and delivery of CFTR protein to the cell surface are equally important to relieve the symptoms of CF, CFTR combination therapies using lumacaftor/ivacaftor or tezacaftor/ivacaftor have emerged effective agents for treating patients with Class 2 [45]. Amplifiers such as PTI-428 facilitate CFTR protein synthesis and are currently being tested in clinical trials (Table 3).

Beyond CFTR modulators, several other small molecule agents targeting other CF-associated genes have already completed phase 4 in clinical trials. For example, previous studies showing that increased levels of Matrix metallopeptidase (MMP-9) is associated with more severe lung disease in CF prompted the development of doxycycline, an antibiotic that is also a potent inhibitor for MMP-9, as a CF therapeutic [50]. In addition, with studies showing that CF patients lack sufficient levels of vitamin D crucial for host defense against microorganisms, Cholecalciferol was developed as an agonist targeting the vitamin $\mathrm{D}$ receptor $(V D R)$ gene which encodes the nuclear hormone receptor for vitamin D3 [51] (Table 3).

Although small molecule agents have produced tremendous clinical results, large molecule agents are becoming increasingly important candidates for $\mathrm{CF}$ therapies. Large protein molecules or biologics are copies of endogenous human proteins that act by binding to specific cell receptors associated with a disease process [52]. Several drugs targeting genes encoding receptor molecules are currently being tested in clinical trials for CF. These include growth hormone receptor $(G H R)$, interferon- $\gamma$ receptor 1 (IFNGR1), interferon- $\gamma$ receptor 2 (IFNGR2), and insulin receptor (INSR) (Table 3). Although these four 
targets were initially identified with other screening methods to be dysregulated in CF [49], IFNGR1, and IFNGR2 were among the top genes we identified via transcriptome profiling of CF plasma-induced signatures [27]. Thus, the findings are an indication that advanced high-throughput transcriptome profiling methods hold promise as robust tools for identification of novel molecular targets with therapeutic potential in CF.

\section{Emerging Targets for Transcriptome Profiling}

As shown in Table 1, the vast majority of CF studies have focused on differential gene expression analysis. We describe emerging targets for transcriptome profiling below.

\subsection{Non-Coding RNAs}

Expression profiling of non-coding RNAs (ncRNAs) is emerging as an approach for identifying new therapeutic targets for $\mathrm{CF}$, based on the crucial role these molecules play as master regulators of gene expression and biological processes [53]. Although there are several species of ncRNAs, microRNAs (miRNAs) and long non-coding RNAs (lncRNAs) are the two most studied regulatory ncRNAs because they have been implicated in many human diseases [54].

Briefly, miRNAs are short single-stranded small ncRNA species (20-25 nucleotides in length) that modulate the expression of their target genes by base-pairing with their complementary sequence. The altered expression of several miRNAs has been reported in a wide range of human diseases including cancers [55,56] and chronic respiratory diseases such as asthma, chronic obstructive pulmonary disease, and CF [57]. In CF, transcriptome profiling has provided some insights into their abundance in epithelial cells and their potential role in the disease progression [54,58,59]. For example, increased expression levels of miR-155 was observed in CF bronchial epithelial cells via microarray profiling which implicated proinflammatory expression of IL-8 [59]. In addition, expression profiling via microarray identified 92 miRNAs differentially expressed between CF and non-CF bronchial brushings. In particular, altered expression of miR-126 was associated with impaired innate immune responses in the CF airway [60]. Because these miRNAs target important genes involved in many immune pathways, their altered expression is highlighted to have deleterious consequences for innate immune responses triggered in the CF airway [54].

Similar to miRNAs, lncRNAs can act as activators or repressors of gene expression. LncRNAs are large (>200 nucleotides in length) ncRNA species that localize to the nucleus or cytoplasm, with a capacity to interact with DNA, RNA, and protein [61]. The regulatory role of lncRNAs in biological processes such as chromatin modification, transcription, and post-transcriptional processing, and intracellular trafficking is well-documented [53,62]. Aberrant expression of lncRNAs has been implicated in many respiratory diseases [63] including CF, where BGas lncRNA was demonstrated to regulate CFTR expression [64]. Although the identification and functional characterization of other lncRNAs potentially relevant to CF have not been pursued extensively, transcriptome profiling approaches are beginning to provide new insights into their role in CF. Following microarray profiling of 30,586 lncRNAs, a total of 1063 lncRNAs from bronchial epithelial cells were identified as differentially expressed between CF and non-CF samples. The aberrant expression of these lncRNAs were suggested to play crucial roles in CF lung infection and inflammation [65]. More recently, by analyzing the transcriptome datasets from primary CF and non-CF epithelial cells infected with $P$. aeruginosa, investigators identified a unique lncRNA profile characterizing CF and potentially relevant to the impaired immune response seen in patients [66]. In addition, a recent study utilizing transcriptome profiling by microarray identified 91 ncRNAs dysregulated in CF airway epithelial cells. Further mechanistic analyses indicated linc-SUMF1-2 was associated with the aberrant expression of genes such as MYC and CXCL10 in CF airway epithelial cells [67].

As the expression of ncRNAs can be modulated in vitro or in vivo to mediate the expression of their target gene [68], including CFTR [69], the identification of dysregulated ncRNAs in CF cells may open new horizons for therapeutics. 


\subsection{Alternate Splicing and Cystic Fibrosis-Relevant Transcript Isoforms}

Alternative splicing is an important biological mechanism through which most mammalian genes generate distinct transcript isoforms that can have diverse functions in different cell-types or disease states [70,71]. Mammalian splicing machinery is regulated by splicing factors that encode protein molecules that facilitate the precise selection of splicing sites and subsequent splicing processes essential for mRNA maturation and protein synthesis [72]. Disruption of these splicing programs can negatively impact on cellular functions and potentially result in human diseases [71]. Both altered expression levels of splicing factors and transcript isoforms can be simultaneously quantified via transcriptome profiling methods. This approach has already led to the discovery and characterization of several dysregulated disease-specific isoforms in recent times [71,73,74]. Although the literature is still sparse with regard to genome-wide implications of aberrant alternative splicing in CF progression, a recent study utilizing transcriptome profiling by RNA-Sequencing identified 83 transcript isoforms in blood neutrophils that distinguished CF following treatment for exacerbation [26]. Thus, identifying the CF-specific isoforms of key genes may be useful for discovering novel diagnostic and therapeutic targets.

\section{Challenges for Cystic Fibrosis Transcriptomics Studies}

Although transcriptome profiling holds promise for revolutionizing our understanding of the molecular complexities of CF and its phenotypes in any cell type, barriers to this approach include the lack of useful model systems and cellular heterogeneity. These challenges limit the capacity of these advanced technologies to identify new therapeutic opportunities in CF.

\subsection{Lack of Useful Model Systems}

The availability of well-characterized model systems for transcriptome profiling has been instrumental in understanding the pathogenesis of many diseases and developing effective therapies [75]. Shortly after the discovery of the CFTR gene in 1989, the first mouse models were developed [76,77]. These models enhanced our understanding of basic CFTR function but failed to exhibit the characteristic lung and pancreatic phenotypes seen in humans [77]. A few years later, there were calls for utilizing other animal models that share close CFTR protein sequence similarity with humans [78]. The CFTR-Knockout pig and ferret exhibiting human phenotypic characteristics were then generated about a decade ago $[79,80]$. Much knowledge about the major consequences of dysfunctional CFTR such as impaired immune responses has been enhanced by intensively studying animal models and cell lines [80]. Impressively, these models also led to the development of therapies that have successfully improved health outcomes in patients [48]. However, with over 2000 CFTR mutations identified so far that can result in phenotypic differences [4], there is a pressing need to identify useful model systems that can effectively characterize variability in CF phenotypes and allow us to take advantage of advanced high-throughput transcriptomic methods.

One human model system that can be used effectively to distinguish disease phenotypes at transcriptome level is the human PBMCs-based model. This system reflects host immune cell responses to external stimuli that can be measured quantitatively at mRNA level using transcriptome profiling approaches. Human PBMCs stimulated with plasma or serum from patients followed by transcriptome profiling have provided new insights into diseases [81,82]. Recently, we used this model to reveal dysregulated expression of a diverse range of genes encoding molecules crucial for important immune pathways in CF $[17,27]$. Although this model system is limited by the cellular heterogeneity of PBMCs, it provides a useful resource to quantitatively profile immune cells via transcriptomic approaches. Of note, recent advances in gene editing technologies such as CRISPR/Cas9 are expected to generate new CF models that will eventually overcome the challenge due to the lack of model systems [80]. 


\subsection{Bulk Transcriptome Profiling}

Although transcriptome profiling approaches have fueled many important discoveries in CF (Table 1), most studies have performed bulk transcriptome profiling, which implies that the generated gene expression data may not be driven by individual cells but by the thousands to millions of cells present in the sample. As different cell-types within the same population can have different transcriptional profiles, which may also be influenced by different physiological conditions and disease states [83], it has become imperative to decipher cellular heterogeneity at a single-cell level.

New computational algorithms and transcriptome profiling at single-cell resolution have emerged as novel approaches to tackle challenges due to bulk sampling. Several computational methods capable of delineating cellular heterogeneity based on gene expression datasets generated from bulk transcriptome profiling have been developed [84-86]. However, a major drawback of the computational approaches is their inability to profile and distinguish the transcriptome of individual cell-types present in the sample. Single cell transcriptome profiling by RNA-Sequencing method (scRNA-Seq) have recently emerged as a robust approach to simultaneously identify novel cell-types, estimate cell-type abundance, and quantify gene expression levels at a single-cell resolution $[83,87]$. Although scRNA-Seq has not been utilized to extensively characterize CF and its phenotypes, a recently published study employing scRNA-Seq to characterize human and mouse airway epithelial cells identified pulmonary ionocyte as a new CFTR-enriched cell-type [87]. Generally, scRNA-Seq is still at an early stage for use in transcriptome profiling and are very expensive and computationally very demanding. However, it offers an apparent solution to the challenges posed by bulk transcriptome profiling and may open new avenues for $\mathrm{CF}$ therapy.

\section{Conclusions and Future Directions}

In just a few years, transcriptome profiling has expanded our understanding of CF pathophysiology. We have learned from the past studies that mutations in CFTR gene result in aberrant expression of genes encoding molecules relevant to several altered biological pathways in $\mathrm{CF}$, prominently signal transduction and immune pathways. Although much of this knowledge seems to have been gained by studying airway epithelial cells, few studies have analyzed blood cells. Together, these studies indicate impaired immune responses is a dominant feature of CF. With data from GTEx confirming that CFTR is abundantly expressed in many unexplored tissues and organs, future studies focusing on such targets will elucidate molecular mechanisms underlying how dysfunctional CFTR results in a multisystem CF disease. Beyond the identification of dysregulated genes in CF cells, identification of CF-specific isoforms from multiple-isoform genes may reveal novel molecular targets for specific therapy. Current knowledge of dysregulated genes in CF transcriptomes are based on analyzing bulk cells. Recent computational algorithms and novel molecular methods such as scRNA-Seq will allow researchers to decipher cellular heterogeneity in gene transcription signatures. Taking advantage of transcriptome profiling will open new horizons for better and specific therapies for CF.

Author Contributions: Writing and original draft preparation: J.E.I. Writing-review and editing: J.E.I., X.Z., S.M., and H.L.

Funding: This work was supported by the National Institutes of Health (DP2OD-007031 to H.L.) and Stanley Manne Children's Research Fund (939001 to H.L.).

Conflicts of Interest: The authors declare no conflict of interest.

\section{References}

1. Madacsy, T.; Pallagi, P.; Maleth, J. Cystic fibrosis of the pancreas: The role of CFTR channel in the regulation of intracellular $\mathrm{Ca}(2+)$ signaling and mitochondrial function in the exocrine pancreas. Front. Physiol. 2018, 9, 1585. [CrossRef] [PubMed] 
2. Riordan, J.R.; Rommens, J.M.; Kerem, B.; Alon, N.; Rozmahel, R.; Grzelczak, Z.; Zielenski, J.; Lok, S.; Plavsic, N.; Chou, J.L.; et al. Identification of the cystic fibrosis gene: Cloning and characterization of complementary DNA. Science 1989, 245, 1066-1073. [CrossRef] [PubMed]

3. Veit, G.; Avramescu, R.G.; Chiang, A.N.; Houck, S.A.; Cai, Z.; Peters, K.W.; Hong, J.S.; Pollard, H.B.; Guggino, W.B.; Balch, W.E.; et al. From CFTR biology toward combinatorial pharmacotherapy: Expanded classification of cystic fibrosis mutations. Mol. Biol. Cell 2016, 27, 424-433. [CrossRef] [PubMed]

4. Fajac, I.; Wainwright, C.E. New treatments targeting the basic defects in cystic fibrosis. Presse Med. 2017, 46, E165-E175. [CrossRef] [PubMed]

5. Carithers, L.J.; Moore, H.M. The genotype-tissue expression (GTEx) project. Biopreserv. Biobank. 2015, 13, 307-308. [CrossRef] [PubMed]

6. Burney, T.J.; Davies, J.C. Gene therapy for the treatment of cystic fibrosis. Appl. Clin. Genet. 2012, 5, $29-36$. [PubMed]

7. Cooney, A.L.; McCray, P.B., Jr.; Sinn, P.L. Cystic fibrosis gene therapy: Looking back, looking forward. Genes (Basel) 2018, 9, 538. [CrossRef] [PubMed]

8. Mekus, F.; Ballmann, M.; Bronsveld, I.; Bijman, J.; Veeze, H.; Tummler, B. Categories of $\Delta$ F508 homozygous cystic fibrosis twin and sibling pairs with distinct phenotypic characteristics. Twin Res. 2000, 3, 277-293. [CrossRef] [PubMed]

9. Corvol, H.; Blackman, S.M.; Boelle, P.Y.; Gallins, P.J.; Pace, R.G.; Stonebraker, J.R.; Accurso, F.J.; Clement, A.; Collaco, J.M.; Dang, H.; et al. Genome-wide association meta-analysis identifies five modifier loci of lung disease severity in cystic fibrosis. Nat. Commun. 2015, 6, 8382. [CrossRef] [PubMed]

10. Kormann, M.S.D.; Dewerth, A.; Eichner, F.; Baskaran, P.; Hector, A.; Regamey, N.; Hartl, D.; Handgretinger, R.; Antony, J.S. Transcriptomic profile of cystic fibrosis patients identifies type I interferon response and ribosomal stalk proteins as potential modifiers of disease severity. PLoS ONE 2017, 12, e0183526. [CrossRef] [PubMed]

11. Worgall, S.; Heguy, A.; Luettich, K.; O'Connor, T.P.; Harvey, B.G.; Quadri, L.E.; Crystal, R.G. Similarity of gene expression patterns in human alveolar macrophages in response to Pseudomonas aeruginosa and Burkholderia cepacia. Infect. Immun. 2005, 73, 5262-5268. [CrossRef] [PubMed]

12. Wright, J.M.; Merlo, C.A.; Reynolds, J.B.; Zeitlin, P.L.; Garcia, J.G.; Guggino, W.B.; Boyle, M.P. Respiratory epithelial gene expression in patients with mild and severe cystic fibrosis lung disease. Am. J. Respir. Cell Mol. Biol. 2006, 35, 327-336. [CrossRef] [PubMed]

13. Verhaeghe, C.; Remouchamps, C.; Hennuy, B.; Vanderplasschen, A.; Chariot, A.; Tabruyn, S.P.; Oury, C.; Bours, V. Role of IKK and ERK pathways in intrinsic inflammation of cystic fibrosis airways. Biochem. Pharmacol. 2007, 73, 1982-1994. [CrossRef] [PubMed]

14. Ribeiro, C.M.; Hurd, H.; Wu, Y.; Martino, M.E.; Jones, L.; Brighton, B.; Boucher, R.C.; O'Neal, W.K. Azithromycin treatment alters gene expression in inflammatory, lipid metabolism, and cell cycle pathways in well-differentiated human airway epithelia. PLoS ONE 2009, 4, e5806. [CrossRef] [PubMed]

15. Ogilvie, V.; Passmore, M.; Hyndman, L.; Jones, L.; Stevenson, B.; Wilson, A.; Davidson, H.; Kitchen, R.R.; Gray, R.D.; Shah, P.; et al. Differential global gene expression in cystic fibrosis nasal and bronchial epithelium. Genomics 2011, 98, 327-336. [CrossRef] [PubMed]

16. Hampton, T.H.; Ballok, A.E.; Bomberger, J.M.; Rutkowski, M.R.; Barnaby, R.; Coutermarsh, B.; Conejo-Garcia, J.R.; O'Toole, G.A.; Stanton, B.A. Does the $\triangle$ F508-CFTR mutation induce a proinflammatory response in human airway epithelial cells? Am. J. Physiol. Lung Cell. Mol. Physiol. 2012, 303, L509-L518. [CrossRef] [PubMed]

17. Levy, H.; Wang, X.; Kaldunski, M.; Jia, S.; Kramer, J.; Pavletich, S.J.; Reske, M.; Gessel, T.; Yassai, M.; Quasney, M.W.; et al. Transcriptional signatures as a disease-specific and predictive inflammatory biomarker for type 1 diabetes. Genes Immun. 2012, 13, 593-604. [CrossRef] [PubMed]

18. Clarke, L.A.; Sousa, L.; Barreto, C.; Amaral, M.D. Changes in transcriptome of native nasal epithelium expressing F508del-CFTR and intersecting data from comparable studies. Respir. Res. 2013, 14, 38. [CrossRef] [PubMed]

19. Mayer, M.L.; Blohmke, C.J.; Falsafi, R.; Fjell, C.D.; Madera, L.; Turvey, S.E.; Hancock, R.E. Rescue of dysfunctional autophagy attenuates hyperinflammatory responses from cystic fibrosis cells. J. Immunol. 2013, 190, 1227-1238. [CrossRef] [PubMed] 
20. Stanke, F.; van Barneveld, A.; Hedtfeld, S.; Wolfl, S.; Becker, T.; Tummler, B. The CF-modifying gene EHF promotes p.Phe508del-CFTR residual function by altering protein glycosylation and trafficking in epithelial cells. Eur. J. Hum. Genet. 2014, 22, 660-666. [CrossRef] [PubMed]

21. Chesne, J.; Danger, R.; Botturi, K.; Reynaud-Gaubert, M.; Mussot, S.; Stern, M.; Danner-Boucher, I.; Mornex, J.F.; Pison, C.; Dromer, C.; et al. Systematic analysis of blood cell transcriptome in end-stage chronic respiratory diseases. PLoS ONE 2014, 9, e109291. [CrossRef] [PubMed]

22. Voisin, G.; Bouvet, G.F.; Legendre, P.; Dagenais, A.; Masse, C.; Berthiaume, Y. Oxidative stress modulates the expression of genes involved in cell survival in $\Delta \mathrm{F} 508$ cystic fibrosis airway epithelial cells. Physiol. Genomics 2014, 46, 634-646. [CrossRef] [PubMed]

23. O'Neal, W.K.; Gallins, P.; Pace, R.G.; Dang, H.; Wolf, W.E.; Jones, L.C.; Guo, X.; Zhou, Y.H.; Madar, V.; Huang, J.; et al. Gene expression in transformed lymphocytes reveals variation in endomembrane and HLA pathways modifying cystic fibrosis pulmonary phenotypes. Am. J. Hum. Genet. 2015, 96, 318-328. [CrossRef] [PubMed]

24. Zeitlin, P.L.; Diener-West, M.; Callahan, K.A.; Lee, S.; Talbot, C.C., Jr.; Pollard, B.; Boyle, M.P.; Lechtzin, N. Digitoxin for airway inflammation in cystic fibrosis: Preliminary assessment of safety, pharmacokinetics, and dose finding. Ann. Am. Thorac. Soc. 2017, 14, 220-229. [PubMed]

25. Polineni, D.; Dang, H.; Gallins, P.J.; Jones, L.C.; Pace, R.G.; Stonebraker, J.R.; Commander, L.A.; Krenicky, J.E.; Zhou, Y.H.; Corvol, H.; et al. Airway mucosal host defense is key to genomic regulation of cystic fibrosis lung disease severity. Am. J. Respir. Crit. Care Med. 2017, 197, 79-93. [CrossRef] [PubMed]

26. Jiang, K.; Poppenberg, K.E.; Wong, L.; Chen, Y.; Borowitz, D.; Goetz, D.; Sheehan, D.; Frederick, C.; Tutino, V.M.; Meng, H.; et al. RNA sequencing data from neutrophils of patients with cystic fibrosis reveals potential for developing biomarkers for pulmonary exacerbations. J. Cyst. Fibros. 2018. [CrossRef] [PubMed]

27. Levy, H.; Jia, S.; Pan, A.; Zhang, X.; Kaldunski, M.L.; Nugent, M.L.; Reske, M.; Feliciano, R.A.; Quintero, D.; Renda, M.M.; et al. Identification of molecular signatures of cystic fibrosis disease status using plasma-based functional genomics. Physiol. Genom. 2019, 51, 27-41. [CrossRef] [PubMed]

28. Casamassimi, A.; Federico, A.; Rienzo, M.; Esposito, S.; Ciccodicola, A. Transcriptome profiling in human diseases: New advances and perspectives. Int. J. Mol. Sci. 2017, 18, 1652. [CrossRef] [PubMed]

29. Kasoju, N.; Wang, H.; Zhang, B.; George, J.; Gao, S.; Triffitt, J.T.; Cui, Z.; Ye, H. Transcriptomics of human multipotent mesenchymal stromal cells: Retrospective analysis and future prospects. Biotechnol. Adv. 2017, 35, 407-418. [CrossRef] [PubMed]

30. Shi, L.; Yu, L.; Zou, F.; Hu, H.; Liu, K.; Lin, Z. Gene expression profiling and functional analysis reveals that p53 pathway-related gene expression is highly activated in cancer cells treated by cold atmospheric plasma-activated medium. PeerJ 2017, 5, e3751. [CrossRef] [PubMed]

31. Westermann, A.J.; Barquist, L.; Vogel, J. Resolving host-pathogen interactions by dual RNA-seq. PLoS Pathogens 2017, 13, e1006033. [CrossRef] [PubMed]

32. Thomas, J.W.; Touchman, J.W.; Blakesley, R.W.; Bouffard, G.G.; Beckstrom-Sternberg, S.M.; Margulies, E.H.; Blanchette, M.; Siepel, A.C.; Thomas, P.J.; McDowell, J.C.; et al. Comparative analyses of multi-species sequences from targeted genomic regions. Nature 2003, 424, 788-793. [CrossRef] [PubMed]

33. Collawn, J.F.; Matalon, S. CFTR and lung homeostasis. Am. J. Physiol. Lung Cell. Mol. Physiol. 2014, 307, L917-L923. [CrossRef] [PubMed]

34. Byrne, A.J.; Maher, T.M.; Lloyd, C.M. Pulmonary macrophages: A new therapeutic pathway in fibrosing lung disease? Trends Mol. Med. 2016, 22, 303-316. [CrossRef] [PubMed]

35. Ratner, D.; Mueller, C. Immune responses in cystic fibrosis: Are they intrinsically defective? Am. J. Respir. Cell Mol. Biol. 2012, 46, 715-722. [CrossRef] [PubMed]

36. Del Porto, P.; Cifani, N.; Guarnieri, S.; Di Domenico, E.G.; Mariggio, M.A.; Spadaro, F.; Guglietta, S.; Anile, M.; Venuta, F.; Quattrucci, S.; et al. Dysfunctional CFTR alters the bactericidal activity of human macrophages against Pseudomonas aeruginosa. PLoS ONE 2011, 6, e19970.

37. Ideozu, J.E.; Zhang, X.; Pan, A.; Ashrafi, Z.; Woods, K.J.; Hessner, M.J.; Simpson, P.; Levy, H. Increased expression of plasma-induced ABCC1 mRNA in cystic fibrosis. Int. J. Mol. Sci. 2017, 18, 1752. [CrossRef] [PubMed]

38. Kiel, C.; Yus, E.; Serrano, L. Engineering signal transduction pathways. Cell 2010, 140, 33-47. [CrossRef] [PubMed] 
39. Reilly, R.; Mroz, M.S.; Dempsey, E.; Wynne, K.; Keely, S.J.; McKone, E.F.; Hiebel, C.; Behl, C.; Coppinger, J.A. Targeting the PI3K/AKT/mTOR signalling pathway in cystic fibrosis. Sci. Rep. 2017, 7, 7642. [CrossRef] [PubMed]

40. Glick, D.; Barth, S.; Macleod, K.F. Autophagy: Cellular and molecular mechanisms. J. Pathol. 2010, $221,3-12$. [CrossRef] [PubMed]

41. Strubberg, A.M.; Liu, J.; Walker, N.M.; Stefanski, C.D.; MacLeod, R.J.; Magness, S.T.; Clarke, L.L. CFTR modulates Wnt/ $\beta$-catenin signaling and stem cell proliferation in murine intestine. Cell. Mol. Gastroenterol. Hepatol. 2018, 5, 253-271. [CrossRef] [PubMed]

42. Bodas, M.; Vij, N. The NF- $\kappa \beta$ signaling in cystic fibrosis lung disease: Pathophysiology and therapeutic potential. Discov. Med. 2010, 9, 346-356. [PubMed]

43. Liu, T.; Zhang, L.; Joo, D.; Sun, S.C. Nf- $\kappa \beta$ signaling in inflammation. Signal Transduct. Target. Ther. 2017, 2, 17023. [CrossRef] [PubMed]

44. Verhaeghe, C.; Delbecque, K.; de Leval, L.; Oury, C.; Bours, V. Early inflammation in the airways of a cystic fibrosis foetus. J. Cyst. Fibros. 2007, 6, 304-308. [CrossRef] [PubMed]

45. Quon, B.S.; Rowe, S.M. New and emerging targeted therapies for cystic fibrosis. BMJ 2016, 352 , i859. [CrossRef] [PubMed]

46. Schwank, G.; Koo, B.K.; Sasselli, V.; Dekkers, J.F.; Heo, I.; Demircan, T.; Sasaki, N.; Boymans, S.; Cuppen, E.; van der Ent, C.K.; et al. Functional repair of CFTR by CRISPR/cas9 in intestinal stem cell organoids of cystic fibrosis patients. Cell Stem Cell 2013, 13, 653-658. [CrossRef] [PubMed]

47. Roy, B.; Zhao, J.; Yang, C.; Luo, W.; Xiong, T.; Li, Y.; Fang, X.; Gao, G.; Singh, C.O.; Madsen, L.; et al. CRISPR/cascade 9-mediated genome editing-challenges and opportunities. Front. Genet. 2018, 9, 240. [CrossRef] [PubMed]

48. Van Goor, F.; Hadida, S.; Grootenhuis, P.D.; Burton, B.; Cao, D.; Neuberger, T.; Turnbull, A.; Singh, A.; Joubran, J.; Hazlewood, A.; et al. Rescue of CF airway epithelial cell function in vitro by a CFTR potentiator, vx-770. Proc. Natl. Acad. Sci. USA 2009, 106, 18825-18830. [CrossRef] [PubMed]

49. Koscielny, G.; An, P.; Carvalho-Silva, D.; Cham, J.A.; Fumis, L.; Gasparyan, R.; Hasan, S.; Karamanis, N.; Maguire, M.; Papa, E.; et al. Open targets: A platform for therapeutic target identification and validation. Nucleic Acids Res. 2017, 45, D985-D994. [CrossRef] [PubMed]

50. Beringer, P.M.; Owens, H.; Nguyen, A.; Benitez, D.; Rao, A.; D'Argenio, D.Z. Pharmacokinetics of doxycycline in adults with cystic fibrosis. Antimicrob. Agents Chemother. 2012, 56, 70-74. [CrossRef] [PubMed]

51. Hermes, W.A.; Alvarez, J.A.; Lee, M.J.; Chesdachai, S.; Lodin, D.; Horst, R.; Tangpricha, V. Prospective, randomized, double-blind, parallel-group, comparative effectiveness clinical trial comparing a powder vehicle compound of vitamin $\mathrm{d}$ with an oil vehicle compound in adults with cystic fibrosis. J. Parenter. Enteral Nutr. 2017, 41, 952-958. [CrossRef] [PubMed]

52. Dalakas, M.C. Immunotherapy in myasthenia gravis in the era of biologics. Nat. Rev. Neurol. 2018, 15, 113-124. [CrossRef] [PubMed]

53. Narozna, B.; Langwinski, W.; Szczepankiewicz, A. Non-coding RNAs in pediatric airway diseases. Genes 2017, 8, 348. [CrossRef] [PubMed]

54. Glasgow, A.M.A.; De Santi, C.; Greene, C.M. Non-coding RNA in cystic fibrosis. Biochem. Soc. Trans. 2018, 46, 619-630. [CrossRef] [PubMed]

55. Hammond, S.M. An overview of microRNAs. Adv. Drug Deliv. Rev. 2015, 87, 3-14. [CrossRef] [PubMed]

56. Peng, Y.; Croce, C.M. The role of microRNAs in human cancer. Signal Transduct. Target. Ther. 2016, 1, 15004. [CrossRef] [PubMed]

57. Stolzenburg, L.R.; Harris, A. The role of microRNAs in chronic respiratory disease: Recent insights. Biol. Chem. 2018, 399, 219-234. [CrossRef] [PubMed]

58. Oglesby, I.K.; McKiernan, P.J. MiRNA expression in cystic fibrosis bronchial epithelial cells. Methods Mol. Biol. 2017, 1509, 57-69. [PubMed]

59. Bhattacharyya, S.; Balakathiresan, N.S.; Dalgard, C.; Gutti, U.; Armistead, D.; Jozwik, C.; Srivastava, M.; Pollard, H.B.; Biswas, R. Elevated miR-155 promotes inflammation in cystic fibrosis by driving hyperexpression of interleukin-8. J. Biol. Chem. 2011, 286, 11604-11615. [CrossRef] [PubMed]

60. Oglesby, I.K.; Bray, I.M.; Chotirmall, S.H.; Stallings, R.L.; O’Neill, S.J.; McElvaney, N.G.; Greene, C.M. MiR-126 is downregulated in cystic fibrosis airway epithelial cells and regulates TOM1 expression. J. Immunol. 2010, 184, 1702-1709. [CrossRef] [PubMed] 
61. Palazzo, A.F.; Lee, E.S. Non-coding RNA: What is functional and what is junk? Front. Genet. 2015, 6, 2. [CrossRef] [PubMed]

62. Ponting, C.P.; Oliver, P.L.; Reik, W. Evolution and functions of long noncoding RNAs. Cell 2009, 136, 629-641. [CrossRef] [PubMed]

63. Xie, N.; Liu, G. NcRNA-regulated immune response and its role in inflammatory lung diseases. Am. J. Physiol. Lung Cell. Mol. Physiol. 2015, 309, L1076-L1087. [CrossRef] [PubMed]

64. Saayman, S.M.; Ackley, A.; Burdach, J.; Clemson, M.; Gruenert, D.C.; Tachikawa, K.; Chivukula, P.; Weinberg, M.S.; Morris, K.V. Long non-coding RNA BGas regulates the cystic fibrosis transmembrane conductance regulator. Mol. Ther. 2016, 24, 1351-1357. [CrossRef] [PubMed]

65. McKiernan, P.J.; Molloy, K.; Cryan, S.A.; McElvaney, N.G.; Greene, C.M. Long noncoding RNA are aberrantly expressed in vivo in the cystic fibrosis bronchial epithelium. Int. J. Biochem. Cell Biol. 2014, 52, 184-191. [CrossRef] [PubMed]

66. Balloy, V.; Koshy, R.; Perra, L.; Corvol, H.; Chignard, M.; Guillot, L.; Scaria, V. Bronchial epithelial cells from cystic fibrosis patients express a specific long non-coding RNA signature upon Pseudomonas aeruginosa infection. Front. Cell Infect. Microbiol. 2017, 7, 218. [CrossRef] [PubMed]

67. Kamei, S.; Maruta, K.; Fujikawa, H.; Nohara, H.; Ueno-Shuto, K.; Tasaki, Y.; Nakashima, R.; Kawakami, T.; Eto, Y.; Suico, M.A.; et al. Integrative expression analysis identifies a novel interplay between CFTR and linc-SUMF1-2 that involves CF-associated gene dysregulation. Biochem. Biophys. Res. Commun. 2019, 509, 521-528. [CrossRef] [PubMed]

68. Li, S.; Qian, T.; Wang, X.; Liu, J.; Gu, X. Noncoding RNAs and their potential therapeutic applications in tissue engineering. Engineering 2017, 3, 3-15. [CrossRef]

69. Fabbri, E.; Tamanini, A.; Jakova, T.; Gasparello, J.; Manicardi, A.; Corradini, R.; Sabbioni, G.; Finotti, A.; Borgatti, M.; Lampronti, I.; et al. A peptide nucleic acid against microRNA miR-145-5p enhances the expression of the cystic fibrosis transmembrane conductance regulator (CFTR) in calu-3 cells. Molecules 2017, 23, 71. [CrossRef] [PubMed]

70. Donaldson, L.F.; Beazley-Long, N. Alternative RNA splicing: Contribution to pain and potential therapeutic strategy. Drug Discov. Today 2016, 21, 1787-1798. [CrossRef] [PubMed]

71. Cieply, B.; Carstens, R.P. Functional roles of alternative splicing factors in human disease. Wiley Interdiscip. Rev. RNA 2015, 6, 311-326. [CrossRef] [PubMed]

72. Kim, H.K.; Pham, M.H.C.; Ko, K.S.; Rhee, B.D.; Han, J. Alternative splicing isoforms in health and disease. Pflugers Arch. 2018, 470, 995-1016. [CrossRef] [PubMed]

73. Niu, L.; Huang, W.; Umbach, D.M.; Li, L. Iuta: A tool for effectively detecting differential isoform usage from RNA-seq data. BMC Genom. 2014, 15, 862. [CrossRef] [PubMed]

74. Stricker, T.P.; Brown, C.D.; Bandlamudi, C.; McNerney, M.; Kittler, R.; Montoya, V.; Peterson, A.; Grossman, R.; White, K.P. Robust stratification of breast cancer subtypes using differential patterns of transcript isoform expression. PLoS Genet. 2017, 13, e1006589. [CrossRef] [PubMed]

75. Khatoon, Z.; Figler, B.; Zhang, H.; Cheng, F. Introduction to RNA-seq and its applications to drug discovery and development. Drug Dev. Res. 2014, 75, 324-330. [CrossRef] [PubMed]

76. Snouwaert, J.N.; Brigman, K.K.; Latour, A.M.; Malouf, N.N.; Boucher, R.C.; Smithies, O.; Koller, B.H. An animal-model for cystic-fibrosis made by gene targeting. Science 1992, 257, 1083-1088. [CrossRef] [PubMed]

77. Mou, H.; Brazauskas, K.; Rajagopal, J. Personalized medicine for cystic fibrosis: Establishing human model systems. Pediatr. Pulmonol. 2015, 50 (Suppl. 40), S14-S23. [CrossRef] [PubMed]

78. Harris, A. Towards an ovine model of cystic fibrosis. Hum. Mol. Genet. 1997, 6, 2191-2193. [CrossRef] [PubMed]

79. Rogers, C.S.; Hao, Y.; Rokhlina, T.; Samuel, M.; Stoltz, D.A.; Li, Y.; Petroff, E.; Vermeer, D.W.; Kabel, A.C.; Yan, Z.; et al. Production of CFTR-null and CFTR- $\triangle$ F508 heterozygous pigs by adeno-associated virus-mediated gene targeting and somatic cell nuclear transfer. J. Clin. Invest. 2008, 118, 1571-1577. [CrossRef] [PubMed]

80. Rosen, B.H.; Chanson, M.; Gawenis, L.R.; Liu, J.H.; Sofoluwe, A.; Zoso, A.; Engelhardt, J.F. Animal and model systems for studying cystic fibrosis. J. Cyst. Fibros. 2018, 17, S28-S34. [CrossRef] [PubMed] 
81. Palatnik, A.; Ye, S.; Kendziorski, C.; Iden, M.; Zigman, J.S.; Hessner, M.J.; Rader, J.S. Identification of a serum-induced transcriptional signature associated with metastatic cervical cancer. PLoS ONE 2017, 12, e0181242. [CrossRef] [PubMed]

82. Kaldunski, M.; Jia, S.A.; Geoffrey, R.; Basken, J.; Prosser, S.; Kansra, S.; Mordes, J.P.; Lernmark, A.; Wang, X.J.; Hessner, M.J. Identification of a serum-induced transcriptional signature associated with type 1 diabetes in the biobreeding rat. Diabetes 2010, 59, 2375-2385. [CrossRef] [PubMed]

83. Kanter, I.; Kalisky, T. Single cell transcriptomics: Methods and applications. Front. Oncol. 2015, 5, 53. [CrossRef] [PubMed]

84. Chen, B.; Khodadoust, M.S.; Liu, C.L.; Newman, A.M.; Alizadeh, A.A. Profiling tumor infiltrating immune cells with cibersort. Methods Mol. Biol. 2018, 1711, 243-259. [PubMed]

85. Bolen, C.R.; Uduman, M.; Kleinstein, S.H. Cell subset prediction for blood genomic studies. BMC Bioinform. 2011, 12, 258. [CrossRef] [PubMed]

86. Aran, D.; Hu, Z.; Butte, A.J. Xcell: Digitally portraying the tissue cellular heterogeneity landscape. Genome Biol. 2017, 18, 220. [CrossRef] [PubMed]

87. Plasschaert, L.W.; Zilionis, R.; Choo-Wing, R.; Savova, V.; Knehr, J.; Roma, G.; Klein, A.M.; Jaffe, A.B. A single-cell atlas of the airway epithelium reveals the CFTR-rich pulmonary ionocyte. Nature 2018, 560, 377-381. [CrossRef] [PubMed]

(C) 2019 by the authors. Licensee MDPI, Basel, Switzerland. This article is an open access article distributed under the terms and conditions of the Creative Commons Attribution (CC BY) license (http:/ / creativecommons.org/licenses/by/4.0/). 